\title{
INTERACTION BETWEEN MELON (CUCUMIS MELO) FLOWERS AND HONEYBEES UNDER EXTREME DESERT CONDITIONS IN ISRAEL
}

\author{
Neta ORR and Dan EISIKOWITCH ${ }^{(*)}$ \\ Department of Botany, The George S. Wise Faculty of Life Sciences, Tel Aviv University
}

\section{SUMMARY}

This study was carried out with melons of the "Arava" variety. It deals with pollination by honeybees in the warm autumn, compared to the cooler spring in Ein-Yahav, which is located in one of the most arid regions in Israel. The ratio between hermaphrodite and staminate flowers and the activity of honeybees in relation to flower phenology and reward are discussed.

\section{INTRODUCTION}

The use of honeybees in pollination of melons in commercial fields is a well known method from the 1920's (RosA, 1924). In Israel it is widely used under Mediterranean climatic conditions. However, experience with the use of honeybees under extreme desert conditions is very scarce and the methods used in other countries are not always found to be suitable for Israeli conditions. Therefore it has been necessary to study melon pollination in order to understand the intimate relationships between the flowers and the pollinators. This study dealt with comparisons between the autumn and spring blooms and their effect on bee activity.

\section{MATERIALS AND METHODS}

The study was carried out in fields of melons cv. "Arava" in Ein-Yahav, located at $30.5^{\circ}$ latitude and $35.5^{\prime \prime}$ Iongitude. This area is in one of the most arid regions in Israel with an average precipitation of Israel.

(*) Reprint requests to D. Eisikowrtch, Department of Botany, Tel Aviv University, Tel Aviv 69978 , 
$42 \mathrm{~mm}$ per annum (range of $9 \mathrm{~mm}-97 \mathrm{~mm}$ ). The temperature is very variable and fluctuates from an average of $38.4^{\circ} \mathrm{C}$ in August to $8.3{ }^{\circ} \mathrm{C}$ in January (Israel Metereological Service 1967).

Fields are drip-irrigated with well water. Plant density was 26400 plants per hectare (4 plants to a running metre).

This region is characterized by two growing seasons : autumn, when plants are sown in August and remain exposed for the whole season, and spring, when plants are sown in January and are protected by plastic tunnels until the flowering period.

Temperature and relative humidity were measured in the fields by the use of a dry/wet mercury thermometer at a height of one metre and recorded at approximately hourly intervals throughout the day. Additional measurements were carried out with a hygrothermograph (« Weather measure »-Japan), at a height of $30 \mathrm{~cm}$.

Bloom counts were begun immediately when hermaphrodite flowers were found on $30 \%$ of the total number of plants. Counts were carried out on 15 tagged plants for a period of 11 days of observations. Calculations were made on an average of the 15 counted plants.

Flower phenology was described starting from the early morning before dehiscence. Fifteen staminate and 15 hermaphrodite flowers were tagged and their phenological stage was recorded hourly until fully opened.

Measurements of nectar secretion were made from the flowers of different plants without removing them from the stems. Samples were removed with $5 \mu \mathrm{l}$ microcapillaries (Drummond) at hourly intervals from staminate $(n=7)$ and hermaphrodite $(n=7)$ flowers.

Pollen amount collected by bees was assessed by collecting anthers during the day ; every sample consisting of 7 staminate and 7 hermaphrodite flowers ; pollen assessment was carried out by observing the open anthers with a dissective microscope and calculating percentage of pollen grains compared to full anthers.

Flowers were bagged with organdy bags $\left(12\right.$ holes $\left./ 1 \mathrm{~mm}^{2}\right)$ thus freely admitting light and air and preventing insect visitation.

Honeybee activity in the field was determined by counting bees hourly during the day by means of a mechanical counter, while walking, at a normal pace, the length of one row $(120 \mathrm{~m}$, two and a half min. walking time). Every honeybee working in the row or crossing at a height of one meter or less, was counted. Results are calculated as bees per 10 metres of row.

\section{RESULTS}

\section{Flower phenology}

Staminate flowers develop in groups, while the hermaphrodite flowers develop separately.

Staminate flowers begin their blooming several days earlier than hermaphrodites. Both types continue their flowering jointly until the end of the blooming period.

A comparison of the climatic conditions between the autumn and spring shows that autumn is generally warmer than the spring season (Fig. 1). These differences in climate are reflected in the differences of the length of the growing season (Table 1, Fig. 1). 

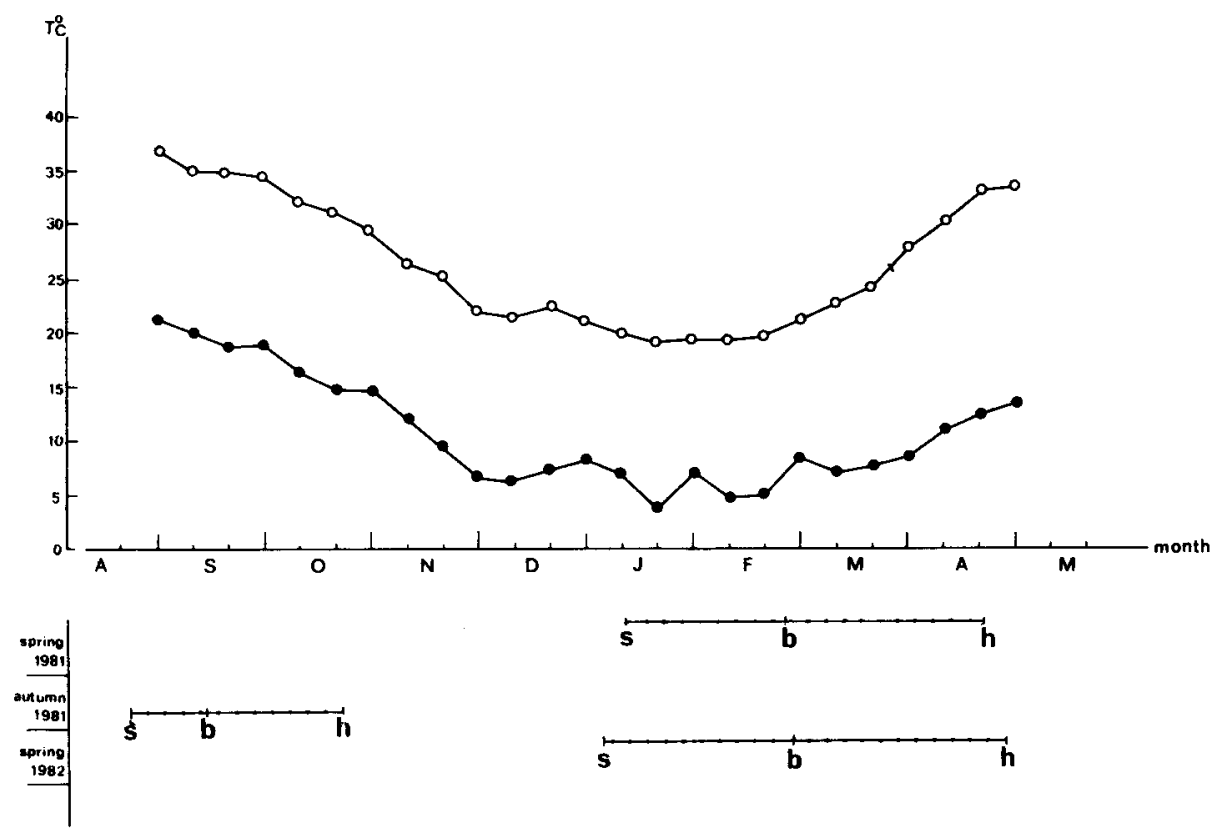

FIG. 1. - Ambient temperature related to growth season in autumn and spring in Ein-Yahav. Open circle - mean of maximum temperature ; Closed circle - mean of monthly minimum temperature. $\mathrm{S}=$ sowing, $\mathrm{b}=$ blooming, $\mathrm{h}=$ harvest.

TABL. 1. - Stages in growth and bloom of Melons cv. "Arava".

\begin{tabular}{l|r|r|r|r}
\hline \hline \multirow{2}{*}{$\begin{array}{c}\text { Observation } \\
\text { period }\end{array}$} & Sowing date & \multicolumn{2}{|c|}{ Commencement of blooming } & \multirow{2}{*}{$\begin{array}{c}\text { Total days } \\
\text { of growth }\end{array}$} \\
\cline { 3 - 4 } & & $\begin{array}{c}\text { Staminate } \\
\text { flowers }\end{array}$ & $\begin{array}{c}\text { Hermaphrodite } \\
\text { flowers }\end{array}$ & \\
\hline Spring 1981 & 12.1 .81 & 26.2 .81 & 8.3 .81 & 100 \\
Autumn 1981 & 22.8 .81 & 13.9 .81 & 17.9 .81 & 60 \\
Spring 1982 & 5.1 .82 & 27.2 .82 & 10.3 .82 & 112 \\
\hline
\end{tabular}

\section{Number and ratio of flowers}

The total number of flowers and the ratio between staminate and hermaphrodite flowers were compared both in autumn and spring. Results show that in autumn the total number of flowers is higher than in spring. However, the number of hermaphrodites, as compared to staminate flowers is higher in spring than in the autumn (Table 2). 
TABL. 2. - Mean number of flowers per plant and ratio between hermaphrodite and staminate flowers.

\begin{tabular}{c|c|c|c|c|c|c}
\hline \hline & \multicolumn{3}{|c|}{ Spring 1981 } & \multicolumn{3}{c}{ Autumn 1981 } \\
\cline { 2 - 7 } observation & $\begin{array}{c}\text { Staminate } \\
\text { flowers } \\
\text { per plant }\end{array}$ & $\begin{array}{c}\text { Hermaphro- } \\
\text { dite flowers } \\
\text { per plant }\end{array}$ & $\begin{array}{c}\text { Ratio } \\
\text { between } \\
\text { herma- } \\
\text { phrodite/ } \\
\text { staminate }\end{array}$ & $\begin{array}{c}\text { Staminate } \\
\text { flowers } \\
\text { per plant }\end{array}$ & $\begin{array}{c}\text { Hermaphro- } \\
\text { dite flowers } \\
\text { per plant }\end{array}$ & $\begin{array}{c}\text { Ratio } \\
\text { between } \\
\text { herma- } \\
\text { phrodite/ } \\
\text { staminate }\end{array}$ \\
\hline 1 & $3.86 \pm 1.06$ & $0.26 \pm 0.45$ & $1 / 14.8$ & $6.53 \pm 1.95$ & $0.86 \pm 0.99$ & $1 / 7.6$ \\
2 & $4.00 \pm 1.13$ & $0.13 \pm 0.53$ & $1 / 30.7$ & $7.33 \pm 3.45$ & $1.53 \pm 0.91$ & $1 / 4.8$ \\
3 & $5.53 \pm 2.09$ & $0.06 \pm 0.25$ & $1 / 92.1$ & $9.73 \pm 3.73$ & $0.80 \pm 0.77$ & $1 / 12.2$ \\
4 & $5.40 \pm 1.54$ & $0.20 \pm 0.41$ & $1 / 27.0$ & $9.86 \pm 3.58$ & $1.40 \pm 1.40$ & $1 / 7.0$ \\
5 & $3.93 \pm 1.43$ & $0.26 \pm 0.45$ & $1 / 15.1$ & $12.20 \pm 4.39$ & $1.66 \pm 1.29$ & $1 / 7.3$ \\
6 & $4.53 \pm 1.50$ & $0.46 \pm 0.51$ & $1 / 9.8$ & $14.33 \pm 3.19$ & $1.46 \pm 1.20$ & $1 / 9.8$ \\
7 & $5.33 \pm 1.79$ & $1.13 \pm 1.12$ & $1 / 4.3$ & $16.73 \pm 5.00$ & $1.33 \pm 1.39$ & $1 / 12.5$ \\
8 & $4.93 \pm 1.62$ & $0.60 \pm 0.73$ & $1 / 8.2$ & $18.00 \pm 4.56$ & $0.53 \pm 0.91$ & $1 / 33.7$ \\
9 & $3.80 \pm 1.26$ & $1.26 \pm 0.45$ & $1 / 3.0$ & $21.20 \pm 5.23$ & $0.33 \pm 0.48$ & $1 / 63.6$ \\
10 & $3.73 \pm 1.22$ & $0.80 \pm 0.67$ & $1 / 8.2$ & $18.73 \pm 5.99$ & $0.13 \pm 0.35$ & $1 / 144$ \\
11 & $3.80 \pm 1.32$ & $0.46 \pm 0.51$ & $1 / 8.2$ & $16.93 \pm 4.74$ & $0.06 \pm 0.25$ & $1 / 282$ \\
\hline $\begin{array}{l}\text { Mean No. No. } \\
\text { and ratio of }\end{array}$ & & & & & & \\
flowers in & & & & & & \\
11 days & $49.8 \pm 9.91$ & $5.62 \pm 1.68$ & $1 / 8.7$ & $153.5 \pm 36.14$ & $10.06 \pm 4.06$ & $1 / 15$ \\
\hline
\end{tabular}

\begin{tabular}{lll} 
Stage & Flower scheme & Flower description \\
\hline A & $\begin{array}{l}\text { mature bud, no entrance to nectar or } \\
\text { pollen }\end{array}$ \\
\hline AB & $\begin{array}{l}\text { petals begin to separate, no entrance to } \\
\text { nectar or pollen }\end{array}$ \\
\hline$B C$ & $\begin{array}{l}\text { petals spread, restricted entrance to } \\
\text { nectar and pollen }\end{array}$ \\
\hline$C$ & $\begin{array}{l}\text { petals continue to spread, stigma and } \\
\text { pollen exposed }\end{array}$ \\
\hline
\end{tabular}

FIG. 2. - Flower scheme anthesis as described by developmental stages. 
Flower anthesis was divided into 3 developmental stages (A-C) according to petal movements (Fig. 2). Anthers dehiscence occurs before the full opening of the corolla (stage B) and is earlier in staminate flowers than in hermaphrodites (a difference of 10-15 minutes).

Normally, changes in stages and anther dehiscence is correlated to the ambient temperature and relative humidity (Fig. 3, 4). At the end of the day, both types of flowers close and on the next morning staminate flowers shrink and drop off, while hermaphrodite flowers open at stage B. However, their corolla is different from the first day by being less wrinkled and by losing its bright yellow colour, having empty anthers and brownish stigma. In the afternoon the hermaphrodite flowers close again and remain closed until the ovule develops.
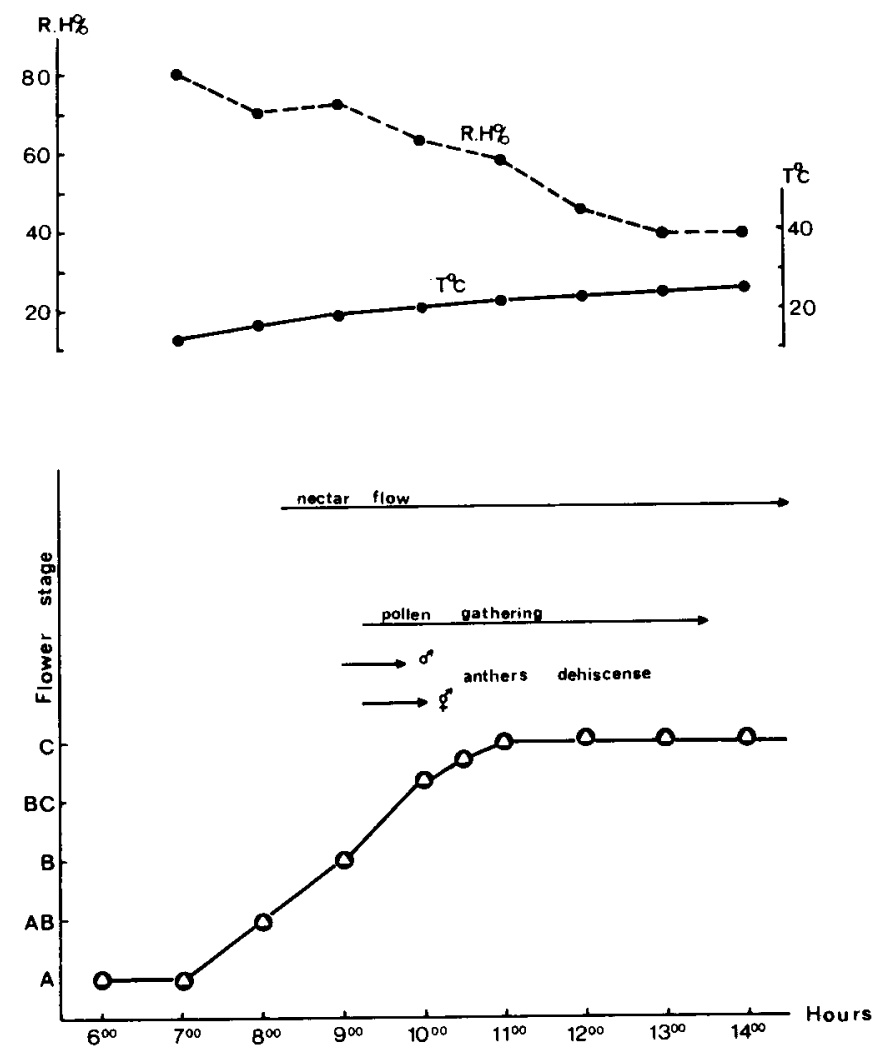

FIG. 3. - Flower anthesis during a spring day compared to ambient temperature and relative humidity. 

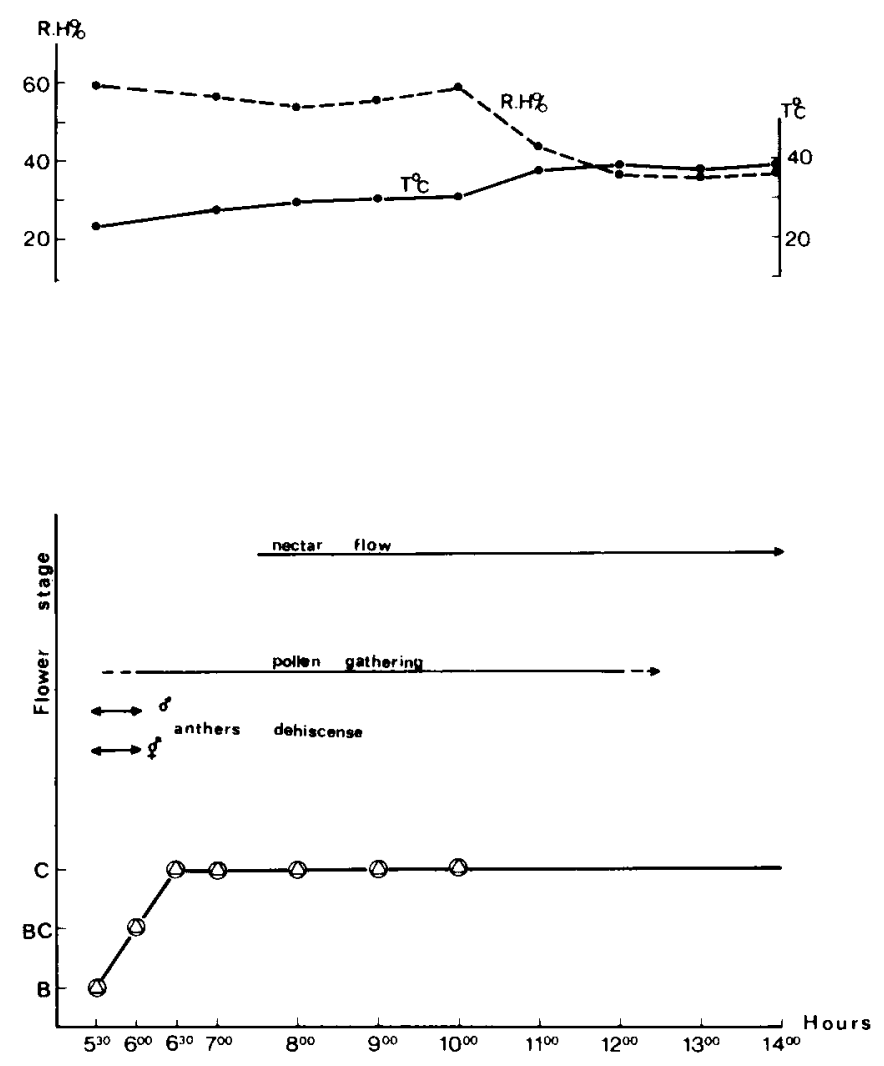

FIG. 4. - Flower anthesis during an autumn day compared to ambient temperature and relative humidity.

\section{Nectar secretion}

Nectar secretion starts at 7.30-8.00 am, at all temperatures observed.

In those flowers which were always subjected to bee activity, nectar volume in staminate flowers ranged between $0.0 \mu \mathrm{l}$ and $1.0 \mu \mathrm{l}$ and in hermaphrodite flowers between $0.0 \quad \mu l$ and $4.0 \quad \mu l \quad(n=7) \quad(O R R$ and EISIKOWITCH, 1987).

Concerning nectar flow, no significant difference could be detected between autumn and spring crops. Flowers protected against bee foraging showed higher nectar secretion in hermaphrodite flowers than in staminate flowers both in autumn and spring crops (Table 3). ( $\mathrm{P}<0.001$, One Way Anova). 
TABL. 3. - Nectar accumulation in bagged flowers during the day in autumn and spring (in $\mu \mathrm{l} \pm \mathrm{S} . \mathrm{D}$. ; $\mathrm{n}=7$ ).

\begin{tabular}{|c|c|c|c|c|}
\hline \multirow{2}{*}{ Hour } & \multicolumn{2}{|c|}{ Spring day 1982} & \multicolumn{2}{|c|}{ Autumn day 1981} \\
\hline & $\begin{array}{l}\text { Hermaphrodite } \\
\text { flowers }\end{array}$ & $\begin{array}{l}\text { Staminate } \\
\text { flowers }\end{array}$ & $\begin{array}{l}\text { Hermaphrodite } \\
\text { flowers }\end{array}$ & $\begin{array}{l}\text { Staminate } \\
\text { flowers }\end{array}$ \\
\hline 6.30 & 0.0 & 0.0 & 0.0 & 0.0 \\
\hline 8.00 & & & $1.87 \pm 0.56$ & $0.25 \pm 0.11$ \\
\hline 8.30 & $1.80 \pm 0.42$ & $0.3 \pm 0.08$ & & \\
\hline 10.00 & & & $2.68 \pm 0.64$ & $0.90 \pm 0.20$ \\
\hline 10.30 & $2.85 \pm 0.72$ & & & \\
\hline 11.30 & & & $4.51 \pm 0.31$ & $1.22 \pm 0.20$ \\
\hline 12.30 & $5.18 \pm 0.17$ & $1.74 \pm 0.18$ & & \\
\hline 13.00 & & & $5.01 \pm 0.30$ & \\
\hline 14.30 & $4.08 \pm 0.64$ & $1.52 \pm 0.31$ & & \\
\hline 16.00 & $2.28 \pm 1.32$ & $0.98 \pm 0.29$ & $2.25 \pm 1.11$ & $0.81 \pm 0.28$ \\
\hline
\end{tabular}

\section{Pollen gathering}

Immediately after anthers dehiscence, bees appear in the field, manipulate the anthers and collect the sticky pollen grains. Autumn flowers are emptied quicker as compared to spring flowers (Table 4). However, protected flowers do not shed their pollen spontaneously and this is kept in the anthers if not visited by bees during the whole day $(n=70)$.

TABL. 4. - Rate of pollen withdrawal during a day.

\begin{tabular}{c|c|c|c}
\hline \multirow{2}{*}{ Season } & $\begin{array}{c}\text { Time } \\
\text { of flower collection }\end{array}$ & \multicolumn{2}{|c}{ Rate of pollen withdrawal in \% } \\
\cline { 2 - 4 } & 8.00 & $\begin{array}{c}\text { Staminate } \\
\text { flowers }\end{array}$ & $\begin{array}{c}\text { Hermaphrodite } \\
\text { flowers }\end{array}$ \\
\hline \multirow{3}{*}{ Spring 1981 } & 10.00 & $0-10$ & $0-10$ \\
& 13.00 & $20-30$ & $20-30$ \\
& 16.00 & $60-90$ & $60-80$ \\
& 7.00 & 100 & 100 \\
\hline \multirow{3}{*}{ Autumn 1981 } & 9.00 & $40-50$ & $30-40$ \\
& 13.00 & $60-80$ & $50-70$ \\
& 16.00 & $95-100$ & $90-100$ \\
& 100 & 100 \\
\hline
\end{tabular}

\section{Bee activity}

Sunrise in autumn took place at the same time as in the spring, i.e. about 5.40-5.50 am. Ambient temperature at this time is higher in autumn by about $10^{\circ} \mathrm{C}$ (Fig. 1). Accordingly, bee activity in autumn begins earlier (Fig. 5) compared to spring activity that starts at about 8.0 am (Fig. 6). In both seasons activity ceases by sunset. 


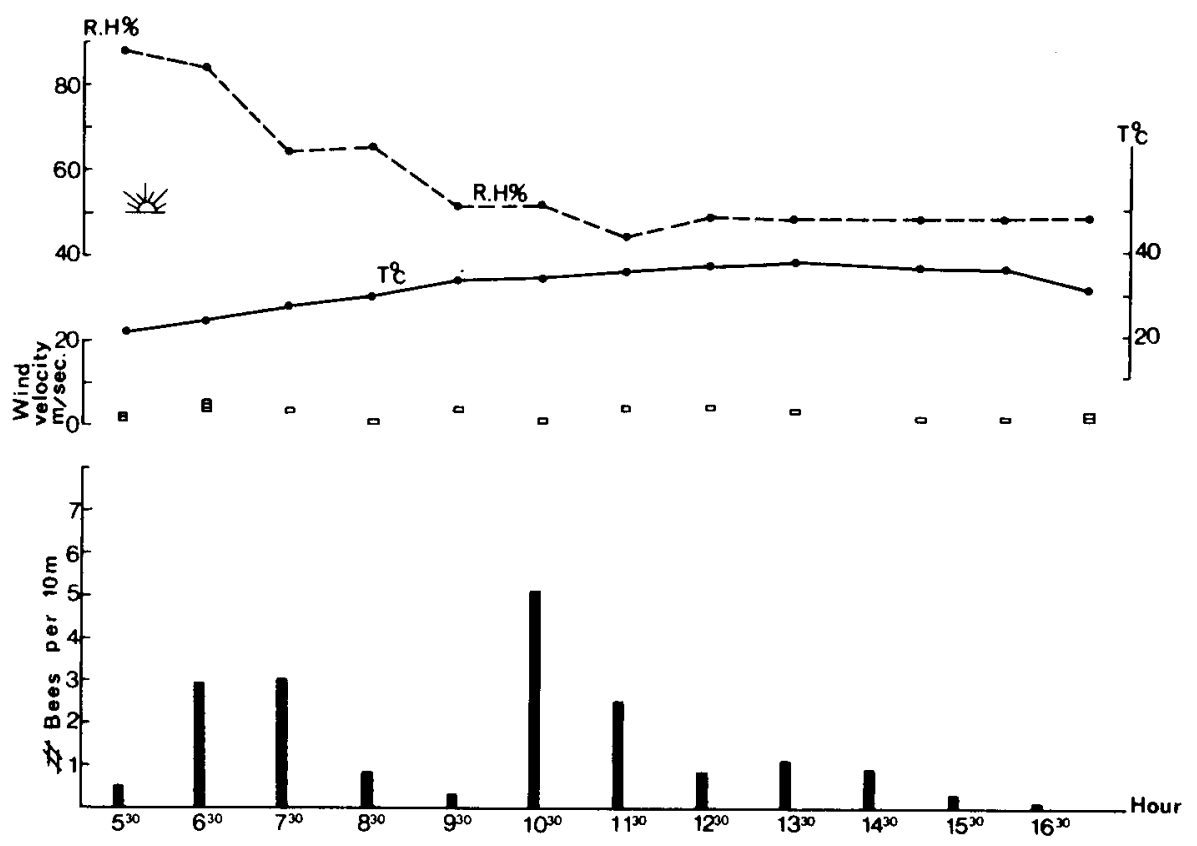

FIG. 5. - Bee activity during an autumn day compared to ambient temperature and relative humidity.
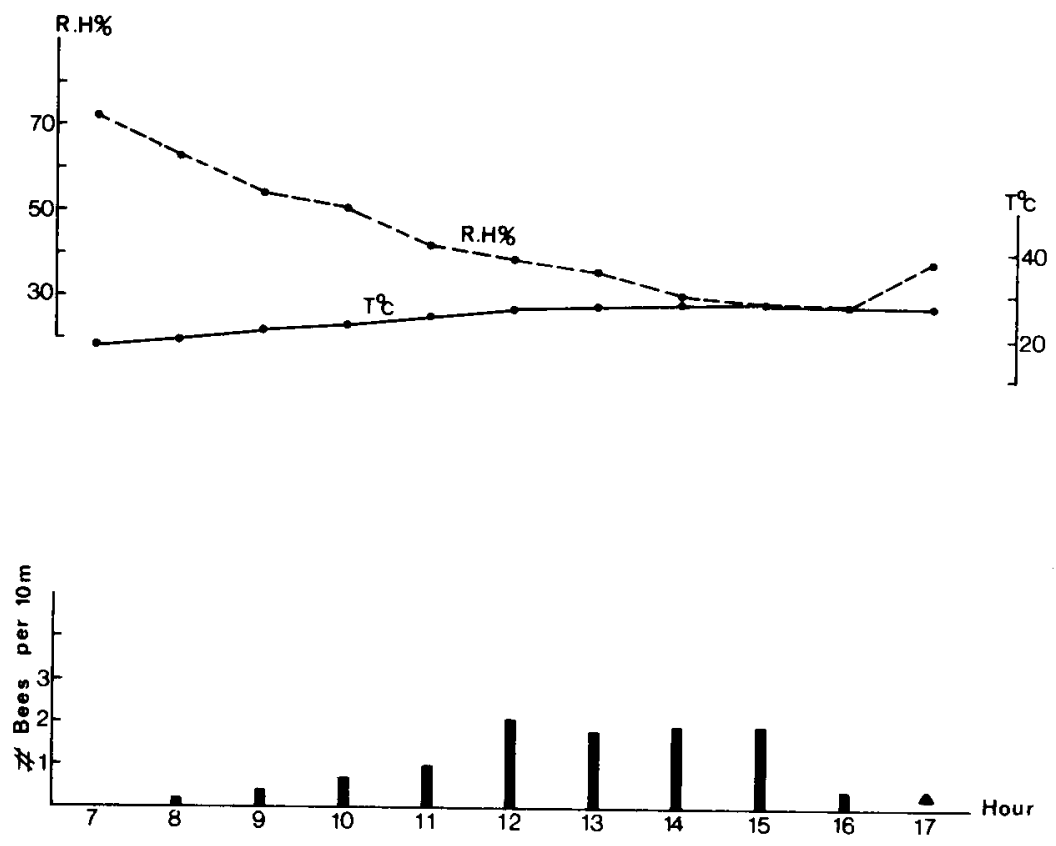

FIG. 6. - Bee activity during a spring day compared to ambient temperature and relative humidity. 


\section{DISCUSSION}

The two seasons dealt with in this paper had similar day-length and light intensity, which are above the minimum needed for optimal growth (KARCHI, 1972). The difference in growth period between the warm autumn and cooler spring can probably be regarded as a result of the difference in temperatures.

Staminate flowers always appear, both in autumn and spring, earlier than the hermaphrodite flowers. This characteristic is widespread in Cucurbitaceae, enabling scouting bees to discover the melon flowers with the aid of " cheap " male flowers. The honeybees which have the ability of memory and communication (von FrISch, 1967), transfer their message of a new food source to other bees, which, in turn reach the promising melon fields. Several days later, when bees establish their working group in the field the «expensive » hermaphrodite flowers appear and are ready for pollination.

As pointed out by Frankel and Galun (1977), the sex expression of monoecious cucumbers is affected by either temperature or changes in day length (see also TAKAHASHI et al., 1983). This is also, in general, probably true for other Cucurbitaceae. Since day length during autumn and spring are equal, the differences in temperature probably have a crucial role to play in ratios between hermaphrodites and staminate flowers. This is supported by the fact that high temperatures raise the endogenic gibberellins compared to auxins, which in turn explains the larger proportion of staminate flowers compared to hermaphrodite flowers in the autumn.

TABL. 5. - Results combined from flower phenology and ambient field temperature.

\begin{tabular}{|c|c|c|c|c|c|c|c|c|c|c|c|}
\hline \multirow{2}{*}{$\begin{array}{l}\text { Fig. } \\
\text { No. }\end{array}$} & \multirow{2}{*}{ Season } & \multirow{2}{*}{$\begin{array}{l}\text { Time of } \\
\text { Sunrise }\end{array}$} & \multirow{2}{*}{$\begin{array}{c}\text { Temp. } \\
\text { at } 6.00 \\
\left(\mathrm{C}^{\circ}\right)\end{array}$} & \multicolumn{2}{|c|}{$\begin{array}{c}\text { Flower } \\
\text { dehiscence }\end{array}$} & \multicolumn{2}{|c|}{$\begin{array}{c}\text { Anther } \\
\text { dehiscence }\end{array}$} & \multicolumn{2}{|c|}{$\begin{array}{l}\text { Fully open } \\
\text { flower }\end{array}$} & \multicolumn{2}{|c|}{$\begin{array}{l}\text { Nectar flow } \\
\text { commencement }\end{array}$} \\
\hline & & & & Time & $\mathrm{T}^{\circ} \mathrm{C}$ & Time & $\mathrm{T}^{\circ} \mathrm{C}$ & Time & $\mathrm{T}^{\circ} \mathrm{C}$ & Time & $\mathrm{T}^{\circ} \mathrm{C}$ \\
\hline 4 & Autumn & 05.40 & 24 & 5.00 & 22 & 5.15 & 23 & 6.30 & 25 & 7.30 & 28 \\
\hline 3 & Spring & 05.40 & 12 & 8.00 & 16 & 9.00 & 19 & 11.00 & 22 & 8.30 & 17 \\
\hline
\end{tabular}

Observation on flower phenology (Table 5) shows that corolla movement, anther dehiscence and nectar secretion do not necessarily occur simultaneously. In autumn flowers may begin their petal movements before sunrise in a relatively high temperature $\left(22^{\circ} \mathrm{C}\right)$, while in spring they open about two-and-ahalf hours after sunrise, even at a lower temperature $\left(16^{\circ} \mathrm{C}\right)$. Certainly, flower opening needs both a certain threshold of temperature and light, both of which conditions are not always available at sunrise. 
Stamen dehiscence seems to be associated with the flower stage (which is controlled by external factors). However, pollen grains are never exposed before the flower reaches Stage B (Fig. 3, 4). Nectar secretion is always two to two-and-a-half hours after sunrise, with no preference as to any particular temperature. This might be explained by endogenous rhythm or by dependency on a certain amount of light and photosynthetic accumulation.

Close examination of anther behaviour shows clearly that in staminate flowers, anthers dehiscence is always earlier than in hermaphrodites (Fig. 3). This may ensure a better chance of first visits on male flowers, so that bees already carrying pollen are the ones to visit the hermaphrodites.

Bee activity in the melon fields during the two seasons was only indirectly affected by differences in temperature. Bees always appear in the field following anther dehiscence. Differences in the daily activity between the two seasons is explained by the fact that in spring, nectar and pollen reward are exposed at the same time, while in autumn the two rewards are presented to the bees separately and therefore their activity is manifested by two separated peaks (Fig. 5). (See also ORR and EISIKowITCH, 1987).

In conclusion, the warm and bright weather in the desert described here, provides conditions that enable the bees to commence their activity at sunrise. In the cooler springtime flowers open relatively late in the day, when bees have already left for foraging on other available targets and may reduce the pollination efficiency of melons. In the warm autumn, melon flowers are the first to bloom and are almost the only ones to offer reward to the honeybees. Therefore they have an excellent visiting rate. However, in spring the demand for pollen and nectar for the bee larvae is much higher compared to the autumn and the late blooming and competition from neighbouring flowers may be compensated for by higher bee activity.

Received for publication in February 1987. Accepted for publication in August 1987.

\section{ACKNOWLEDGEMENT}

This study was supported in part by the Botany Research Fund dedicated to the memory of Tzvi MERIMINSKI and his sister Sonia MeriminsKI. We would also like to thank Mrs. RuTH Direktor for editing and typing the manuscript. 


\title{
RÉSUMÉ
}

\section{INTERACTIONS ENTRE LES FLEURS DE MELON (CUCUMIS MELO) ET LES ABEILLES DANS DES CONDITIONS DÉSERTIQUES EXTRÊMES EN ISRAËL}

L'étude a été menée dans la vallée d'Arava, l'unc des régions les plus arides d'Israël. On a cultivé des melons de la varićté «Arava " sous système d'irrigation de goutte à goutte à deux saisons différentes du point de vue climatique: l'automne chaud et le printemps relativement plus frais (Fig. 1).

La différence entre les deux saisons se répercute à la fois chez les plantes et dans l'activité des abeilles. La période de croissance des plantes pendant l'automne chaud est plus courte qu'au printemps (Tabl. 1). L'anthèse des fleurs a lieu plus rapidement à l'automne qu'au printemps (Fig. 3, 4). Au printemps le nombre total de fleurs est relativement plus faible qu'en automne, mais le nombre de fleurs hermaphrodites est en même temps plus élevé (Tabl. 2). On n'a pas trouvé de différence significative entre les récoltes de printemps et d'automne mais les fleurs hermaphrodites ont secrété plus de nectar que les fleurs staminées, aussi bien à l'automne qu'au printemps (Tabl. 3).

En ce qui concerne la production de pollen, les fleurs d'automne se vident plus rapidement de leur pollen que les fleurs de printemps (Tabl. 4) et cela peut s'expliquer par les différences dans la température ambiante et la phénologie de la fleur (Tabl. 5).

En automne les abeilles sont actives plus tôt et reçoivent une double récompense (pollen et nectar) sur des fleurs séparées. Cette activité élevée est suivie de deux périodes de moindre activité (Fig. 5). Au printemps les abeilles sont actives plus tard et reçoivent ensemble le pollen et le nectar. Cette activité n'est suivie que par un seul pic (Fig. 6).

\section{ZUSAMMENFASSUNG}

\author{
WECHSELWIRKUNGEN ZWISCHEN MELONENBLÜTEN (CUCUMIS MELO) \\ UND HONIGBIENEN UNTER EXTREMEN WÜSTENBEDINGUNGEN IN ISRAEL
}

Die vorliegende Studie wurde in einer der aridesten Regionen Israels im Arava Tal ausgeführt. Die Melonen vom Typ «Arava " wachsen unter Tröpfel-Berieselung zu zwei klimatisch unterschiedlichen Vegetationszeiten : im warmen Herbst und im relativ kühleren Frühling (Abb. 1).

Diese Differenz der beiden Jahreszeiten schlägt sich sowohl bei den Pflanzen als auch in der Aktivität der Honigbienen nieder — die Wachstumsperiode der Pflanzen ist im warmen Herbst kürzer als im Frühling (Tab. 1). Die Blütezeit beginnt im Herbst früher als im Frühling (Abb. 3, 4). Im Frühling ist die Gesamtzahl an Blüten relativ geringer im Vergleich zum Herbst, aber gleichzeitig die Anzahl an hermaphroditen Blüten größer (Tab. 2). Zwischen den Erträgen im Herbst und im Frühling wurden keine signifikanten Unterschiede entdeckt aber die hermaphroditen Blüten sezernierten höhere Mengen an Nektar im Vergleich zu den staminaten Blüten sowohl im Herbst wie im Frühling (Tab. 3).

Bezüglich des Pollenangebots konnte folgendes festgestellt werden : Die Blüten werden im Herbst schneller geleert als im Frühling (Tab. 4). Das könnte mit den Differenzen in der Umgebungstemperatur und mit der Blütenphänologie (Tab. 5) crklärt werden.

Die Aktivität der Bienen beginnt im Herbst früher und die Bienen erhalten ihre beiden Belohnungen (Pollen und Nektar) auf getrennten Blüten. Diese hohe Aktivität wird gefolgt von zwei separaten Perioden geringerer Aktivität (Abb. 5). Im Frühling beginnt die Aktivität der Bienen später aber Pollen und Nektar werden gleichzeitig gesammelt. Diese Aktivität wird nur von einem Gipfel der Bienenaktivität gefolgt (Abb. 6). 


\section{REFERENCES}

Anonymous, 1967. - Israel Metereological Service, The State of Israel.

Frankel R. and Galun E., 1977. - Pollination mechanisms, reproduction and plant breeding. New York, Springer Verlag, $284 \mathrm{p}$.

Frisch K. von, 1967. - The dance language and orientation of bees. Harvard Univ. Press, Cambridge, Mass., $566 \mathrm{p}$.

KarCHI Z., 1972. — «Field Crop » in Encyclopedia of Agriculture. Edit. by H. Halperin, Volume II (in Hebrew).

OrR N. and EISIKowitch D., 1987. - Nectar secretion in Cucumis melo (L.) in relation to environmental conditions and honey bee activity under desert conditions in Israel. J. Apic. Res. (in press).

Rosa J.T., 1924. - Fruiting habit and pollination of Cantaloup. Proc. Am. Soc. Hortic. Sci., 23, 243249.

Takahashi H., Satto T. and Suge H., 1983. - Separation of the effects of photoperiod and hormones on sex expression in cucumber. Plant and Cell Physiol., 24, 147-154. 